\title{
Germany
}

\section{“Protein Separation” (Proteintrennung)}

\section{Decision of the Federal Supreme Court (Bundesgerichtshof) 18 March 2014 - Case No. X ZR 77/12}

Patent Act, Sec. 81; EPC, Art. 54; Patent Act, Sec. 3

Keywords Patent nullity action - Abuse of the law · Patent description · Inclusion of the obvious - Disclosure in the publication

1. A patent nullity action is not to be regarded as an abuse of the law merely because the nullity plaintiff failed to join an earlier action filed by a party against whom an action had been brought for the infringement of the patent at issue as a joined party or intervener, but initially awaited the outcome of these proceedings instead.

2. A prior publication can also disclose what is not expressly mentioned in the patent claim and the description but which is self-evident to the person skilled in the art for the execution of the protected teaching and for this reason does not require separate disclosure but is instead "read into" the document. However, the inclusion of the self-evident does not permit specialist knowledge to be added to the disclosure, but merely serves to identify the complete meaning, i.e. the technical information that the expert reader will derive from the source against the background of his specialist knowledge (confirmation of the decision of this Court of 16 December 2008, Case No. X ZR 89/07 - Olanzapine [40 IIC 596 (2009)]).

3. If from the description of a method to manufacture a protein concentrate suitable for therapeutic use it follows for the person skilled in the art that further process steps are needed to achieve usability for therapeutic purposes, a measure that at the time of priority was the usual means in practice to achieve this objective is covered by the disclosure in the publication.

DW 